\title{
Exploring The Vaw Method Of Writing Among Esl Primary Pupils: Conceptual Paper
}

Dg Nursazwani binti Daud*, Wardatul Akmam Din, Asmaa AlSaqqaf

Faculty of Psychology and Education, Universiti Malaysia Sabah, Malaysia

Corresponding Author: Dg Nursazwani binti Daud, E-mail: dg.nursazwani@gmail.com

\section{ARTICLE INFO}

Received: February 18, 2018

Accepted: April 05, 2018

Published: July 01, 2018

Volume: 7 Issue: 4

Advance access: March 2018

Conflicts of interest: None

Funding: None

\begin{abstract}
The lack of writing skills among rural ESL primary school pupils in Malaysia has been identified based on the school level assessments. Based on the teachers as the researchers' perspectives, the problem of writing among these rural young learners is cause by the lack of vocabulary acquisition where they don't have choices of words in expressing their ideas in writing. Therefore, the researchers propose method with a writing module focusing on vocabulary enhancement in improving the writing skills among these learners. This module i.e. the VAW Module uses the VAW Method that comprises of vocabulary enhancement (V), application and practice (A) and Writing (W) is anticipated to help the pupils to power up their writing before they undergo the Primary School Achievement Test (UPSR) in Year 6 i.e. the national examination taken by all students in Malaysia at the end of their sixth year in primary school before they leave for secondary school.
\end{abstract}

Key words: Vocabulary Learning Strategies, Writing Skills, Vocabulary Enhancement, Improving Writing Skills, Composition Writing, Method, Primary School, ESL

\section{INTRODUCTION}

Teaching and learning English as a second language (L2) refers to teaching English to pupils as young learners whose first language is not English, usually offered in a region where English is the dominant language. Malaysia is one of the Asian countries adopting a bilingual system of education (Ramiza Darmi \& Peter Albion, 2013). In keeping with the Malaysian education policy, English is taught as a second language level of schooling. English provides an additional means of access to academic, professional and recreational materials and the knowledge of English will help Malaysian participate meaningfully in the world community (Siti Katijah Johari, 2004).

Zaidan (1993: $10 \&$ 11) points out the reasons for the efforts to enhance English status in Malaysia is referring to the government target i.e. Vision 2020 by which it hopes to achieve fully developed status, where the nation is ready to be a strong competitor with other developed economically, industrially and technologically, and educationally as well as scientifically. Since English acts as an effective way of communication in this respect, Malaysian today is more emphasizing to improve the English language command seriously by the whole political and educational structure of the country. Meanwhile, Malaysians are required to progress their English language skills to grasp and make sure the advancement of their nation.

In lower educational phases namely primary school, the implementation of the Primary School Standard Curriculum
(KSSR) emphasizes the acquisition of the four modules of language skills includes listening and speaking, reading, writing as well as language arts. Each component or module will be taught to pupils separately but in sequence; starting with Module 1 (Listening and Speaking), then move on to Module 2 (Reading), then Module 3 (Writing) and Module 4 (Language Arts). For Year 3 onwards, after Module 4 the sequence will continue with Module 5 (Grammar).

Writing has always been a challenging task for individuals especially for ELT practitioners. Malaysian ESL teachers agreed that the problems of writing includes in conventions as well as punctuation (Neda Ghabool, 2012). Ambigapathy (2001) as cited in Voon Foo (2007, p. 1) mentioned about a need for the Malaysians future generations to master English as the language has been a prevailing role as a compulsory subject and medium of instruction. Voon Foo (2007, p. 4) also cited writing as a significant tool of learning since it helps pupils to comprehend ideas and concepts properly. Hence, the Malaysian policy makers have decided to highlight it in the mainstream courses.

The deficiency of English language proficiency affects the ESL learners' writing composition. Musa, Lie, \& Azman (2012) states that the L2 students encounter more complex issues either culturally or linguistically. Since it may cause strain for both teachers and ESL writers, so focusing on diverse aspects of variation may aid L2 learners to adapt the standards of writing. Leki (1992) declares that L2 learners have problem to understand the word implication as well as 
meaning. Apparently, there is an inconsistency between writing in the first and the second language as in the classroom. Consequently, the present study meant to suggest some solutions based on pupils' preferences of vocabulary and writing skills in a method or module development.

In producing a writing module for the young learner, there is the need to prepare the effective content to suit the learners' preference. That is the reason why the researchers will produce a module based on the Vocabulary Learning Strategies (VLSs) as well as writing strategies which are most preferred by the learners. The other issue to be considered is the cognitive of the pupils. There is the need to connect the content of the module with pupils cognitively so that they are able to fit in the intervention module process.

\section{APPLICATION OF COGNITIVE THEORY TO L2 WRITING}

Xinyan Li (2008) in her study defines cognitive as the psychological term that refers to the action or process of obtaining knowledge by reasoning, intuition or through senses containing the nature of knowledge and how to apply focusing on active role of human cognitive organism such as sense, understanding and logical thinking in acquiring knowledge.

Cognitive theory provides a new perspective to create a module of writing. Chelala (1981) conducted the first second language writing process studies using a case study approach to identify composing and coherence when she finally found the transfer of L2 writing method. She has found numerous analogical performances when students wrote in their mother tongue and also in English. These students made a simple draft before writing in both languages by considering to language coherence. Next, they were focusing on the substantial in content during revision. Later, many other researches on second language writing undergone by other researchers where all of these studies had proven the second language writing method mainly dominated by the first language (Xinyan Li, 2008; Jones \& Tetroe, 1987; Eldelsky, 1982).

In addition, Vygotsky assumes the development of children consist of a series of periods of infant development. He introduces several unique concepts. One of the concepts that related with learning among young learners includes the Zone of Proximal Development which refers to the variety of psychological functions which the child is able to master without assistance as well as those functions which the child can manage if given assistance. There are several things that a child may see and learn from people around them performing even without coaching or allowing them to imitate. Meanwhile, the range in between these two limits is termed the Zone of Proximal Development. Vygotsky preaches that these functions which lie within the child are something the child can be trained. The efforts to teach the child something beyond their ability even though with assistance is ineffective, and even if it is, we have to wait until the child has further matured than now. If the child can achieve more when given assistance, this shows the development has occurred. If assistance or instruction can bring development of that function then it will lead the development of other functions.
Besides, there are peripheral lines of development as a secondary part of the child's overall development i.e. the reconstruction of their personality to adopt a new interaction within their environment. In these situations, the central neoformation in the Zone of Proximal Development is essential especially if the teacher strives to assist the child for development. However that is what the child needs during the long stable periods of development. Meanwhile, the central line of development is the merging of the central neoformation that describes the complete stage of development.

During the premature stage, while a child is still adapting the neoformation, functioning at the higher level is beyond the child's range. This could happen when the central neoformation has matured. During the constant periods of development, the social situation development assists the child to major the psychological functions within boundaries executed by her social situation development and after struggling, the central neoformation grows and leads the whole development process. Vygotsky believes that carers and teachers will be alert of those psychological functions within the Zone of Proximal Development, and which Neoformations are dominant and also which peripheral. Proper instruction which encourages the endeavoring of the child, the differentiation as well as growth of the main neoformation will support development, while efforts to attract the child in other activity that includes peripheral lines of development or are beyond the child's age level capability are not probable to give any benefit in development.

The essential thing to be considered when choosing the models of writing development both process-related models and product-related models is the relationship between learning and development, and also between writing and meaning-making. Writing is a means of making sense (Forster 1927/1976:99), as meaning-making as well as a means of communicating with others. Vygotsky seen writing as a secondary symbolic system, based on speech which is comprehensible on how such a conception could form in the child which started by speech and followed by writing, and so much more in several ways to represent speech; writing has dialogic properties borrowed from speech; writing systems, at least in the alphabetic written languages based on a broad correspondence with speech-sounds.

Based on the review of literature about writing pedagogy, many researchers have recommended models for writing as processes of cognitive activities. An author named Strömquist denotes to Hayes and Flower's Cognitive Process Theory of Writing model from 1981 where there are diverse stages to go through by the writer which controlled by an over-arching factor such as a component within the writer's writing ability as well as through which the different thought processes in the writing takes place (2007:32).

Brown relates writing and thinking in a very simple way as written products are often the result of thinking (2001:335). He noted that it is this specific point of view that forms the foundation for his principles of writing techniques design. For instance, he mentioned the importance of balancing process and product, account for cultural or literary backgrounds and delivering numerous authentic writing. 
Several literary sources about writing methodology such as Cushing Weigle, Graham, Harmer, Hedge, Strömquist and Unger \& Fleischman mentions the Hayes \& Flower Cognitive Process Theory of Writing model from 1981 as a model that the theory of process writing has initiated. Next, the model was further advanced and updated by Hayes in 1996; however it is rather multifaceted comprising many components. Unger and Fleischman explain about process writing by denoting to Hayes and Flower in a quotation "This approach emerged from researchers' study of the steps that accomplished writers engage in as they write"; planning and organizing ideas, translating ideas into text and reviewing and revising the result" (2004: 90).

Cushing Weigle stresses that the individual is the main focus in the Hayes \& Flower model, not the given task. The individual parts of writing engage interactions among four components of working memory, motivation and affect, cognitive processes as well as long-term memory. She also claims that the Hayes \& Flower model of process writing is based on first-language writing but still it can suit second-language writing.

Strömquist clarifies that writing includes different phases that a writer must go through where the level of awareness about when and how these phases occur can vary. This specific insight forms the foundation of the writing pedagogy i.e. process writing. Strömquist articulates that process writing gives students the opportunity to use both expressive writing and as a tool for learning and thinking too. The process writing is not only a method, but it can be included in teaching with process writing. It consists of accepting an approach as a basic attitude towards writing in its own. Writing is perceived as a complicated as well as complex process and it is this specific insight that leaves traces in the teaching.

Hedge argued if writing skills learnt in first language can be transferred successfully to a second language. She mentions that EFL students not only require linguistic assistance such as syntax and grammar but they also must learn how to organize their texts and ideas since the language is different from another. Brown in his chapter "Research on Second Language Writing" suggests process writing in the EFL classroom as an efficient method in language teaching.

\section{THE MODULE OF VAW METHOD OF WRITING FOR PRIMARY STUDENTS}

This study is focusing on writing at the primary school level i.e. Year 5 ESL young learners. In a first language situation, children rarely write what they do not say or read. Young children listen for sounds as they attempt to use letters to record their ideas on paper (Johnson, 2008: 7). As the teachers, the researchers realized that the problem of writing among these young learners is cause by the lack of vocabulary acquisition where they don't have choices of words to express their idea in writing. Vocabulary has been acknowledged as L2 learners' greatest single source of problems (Meara, 1980). The improvement in the areas of vocabulary and grammar and structures was due to the reason that a lot of reinforcements of new words were done (Nasir; Naqvi \& Bhamani, 2013).

There are the statements made by the experienced English teacher in an educational websites which provide sources of writing program called Time4writing.com mentions "Every good mechanic has a toolbox full of tools. Some tools are used more than others, but each of them has a specific purpose. In much the same way, writers have a 'toolbox'. This 'toolbox' is constantly growing and is filled with items like grammar, punctuation, and capitalization rules; figurative language; rhyme; rhythm; and vocabulary. Just as really good mechanics can pull out the right tools to make a good engine even more powerful, good writers can pull out the right tools at the right time to make good writing even more powerful. One tool that can power up your writing is a strong vocabulary". The researchers agreed with this fascinating explanation based on 5 years of teaching experiences when the pupils have lack ability of writing due to lack of vocabulary. They tend to ask the translation of each unfamiliar word in Malay not only in writing exercises but also in the other three language skills.

In fact, vocabulary is very important to express ourselves in communication between each other. It is also the fundamental in writing because the accuracy and clarity of our messages depends on the words that we choose. Apart from that, the best ways to expand vocabulary is not only by referring to the dictionary but also understanding the usage of the words according to the sentences.

The researchers want to create the module since they are educators and researchers at the same time. As educators, they are facing the challenge of teaching young learners to learn foreign language i.e. the second language which is not their mother tongue and it was found that difficulties they have been encountering in the classroom proven by their assessment results especially in writing production.

In order to shed further light on overcoming this problem, the researchers would like to introduce a three steps approach called VAW methods (Vocabulary Acquisition, Application, Writing). This method will be utilized in the set induction step in every English lesson. The idea focuses more on vocabulary enhancement where the pupils will undergo the new vocabulary drilling in improving their writing skills such as constructing sentences, e-mail or essay writings.

Captivatingly, the VAW technique uses new vocabularies in sentence construction. The approach reinforces the new vocabularies to build sentences in writing. Beside of teaching new vocabularies, the VAW technique is considered as an inclusive program that encompassed techniques of writing etc. The VAW technique is a frisky and unique approach for writings with incorporated strategies to use new words and sounds into memory through instructions. The characteristics of input in a classroom setting for this program depend on the type of instruction. Instruction intended to provide learners with opportunities to communicate written ideas naturally e.g. information gap, fill in the blanks, typically makes no attempt to manipulate the input or output in order to focus on specific items.

The first step in VAW is 'Vocabulary Acquisition'. In this step, the pupils will be introduced with the new vocabularies. For instance teacher will show the flashcards or picture cards of each words whereas the pupils will listen, dictates 
and read the words. The second step is 'application'. In this step, pupils will apply and practice the new found words in language activities such as labelling, listing etc. These activities will take place in twelve cycles. Next, the final step is 'writing' that will be examined before and after the six cycles in order to evaluate the progress of writing production. In this step, pupils will now apply the new words in descriptive writing situation. In sum, the VAW method program will be reinforced in twelve cycles within twelve weeks.

The sample of the study is the year 5 remedial and weak pupils. The expected outcome of the treatments is the improvement of pupils' performances in constructing sentences. This action research emphasizes on the usage of VAW (Vocabulary Acquisition, Application, Writing) method during set inductions to improve weak and remedial pupils' ability in sentence constructions. The respondents consist of 30 primary school pupils from a school in Penampang District, Sabah. These pupils are still lack in writing skills. The method is going to be exposed in twelve cycles and they will be tested at the end of the study to see the comparison before and after the intervention program. Data will be collected and then compared through two separated tests (pre- and post-test) in determining the pupils' strategies and initial abilities whereas the post-test is identifying and analyzing the result of the program intervention.

The current study set out to investigate the attitudes of students towards the VAW method in a Malaysian primary school. This stage will be assessed in the interview sessions with selected samples after the completion of the program. It also assists as an empirical investigation of the VAW method implementation in the program intervention. In particular, it aims to explore the favourable factors and perceive difficulties of VAW method implementation so as to provide implications for the development of English language curriculum and teachers' professional development in Malaysia.

\section{APPLICATION OF VLSS AND WRITING STRATEGIES}

Teachers might help children to retain newly taught information in long term memory. Firstly, they have to understand what memory is, where memory is housed, and how it moves from short term or working memory into long term memory (Sprenger, 2008). Surprisingly, children's brain can only accept and memorize information that attracts his or her attention (Willis, 2010). Instead of giving the information of how this process are, the researchers thought that it is better to make the pupils familiar and practice the input and the said process will come to reality unconsciously or absentmindedly.

In fact, when the pupils use his or her eyes, ears, mouth, and body, as well as practice the smell and taste sensory to play with the new vocabulary, they will master the skills of sentence construction which lead to writing fluency. For instance, when they see new action vocabulary in the shapes of objects, then they can move or gesture like the verb, and also say aloud the sounds of verbs while having fun with some actions like scratching the verbs on sandpaper with cinnamon sticks and tossing beanbags on verbs as they call out the action verbs loudly. Such types of activities will arouse their interest and keep their attention as well.

In addition, pupils' participations in peer or group in performing the playful vocabulary activities could encourage socialization, laughter, and a feeling of safety, which will stimulate the amygdala to open up the doors for memory (Sprenger, 2009; Willis, 2009; Wolf, 2000). They are required to do more practices for them to remember the newly taught material. These materials and have to be prepared and the activities have to be carefully planned since what is rehearsed is remembered (Sousa, 2005).

During the process, the pupils have to master one skill or concept before going on to the next skill. Therefore, repetition and feedback must continuously occur. Meanwhile, the pupils' brain is persistently looking for meaning. According to Wolfe in 2001, teachers have to give the children time to rehearse the information so that their brain can take time to understand and remember. Indeed, curriculum must be designed to meet the physical, social, emotional and biological needs of all children (Gurian \& Stevens, 2005; Medina, 2009; Sprenger, 2008).

\section{CONCLUSION}

Writing is a multifaceted task for individuals especially for the pupils in primary school level. However, there is the need to master the skill for the sake of the future of the young learners. Based on the importance of writing, all Malaysian policy makers especially in terms of education have decided to emphasize it in their mainstream courses. The deficiency of English language proficiency is the main cause of lots of writing problems that faced by the ESL learners in their tasks. These problems may cause difficulty for both teachers and ESL young writers. Therefore, it is crucial to focus on a variety aspects of variation in order to help ESL learners adapt themselves to the standards of writing. So the researchers decided to create this module of writing in order to solve these problems as well as to improve the learners' writing skills.

This method is expected to improve pupils' writing skills through vocabulary enhancement. It is expected to provide adequate information which could improve the language teaching and learning process and also to suggest on the best teaching method or approach especially vocabulary acquisition as well as writing in the early stage of young ESL learners. The findings and outcomes can offer the contributions of the study. If the enhancement of vocabulary among pupils is found to cause the improvement of their writing skills, then the program should be promoted in a particular grade to enhance the ESL teaching and learning.

Academically, this study is expected to be the preliminary information and can be used as a reference for subsequent studies on the effect of educational growth in writing skills. Practically, it is expected as consideration for policy makers in particular to determine the direction and development strategy in the future as well as an evaluation for planning in anticipation of the implementation of the intervention in the VAW method in teaching and learning process. 


\section{ACKNOWLEDGEMENTS}

The author would like to thank her supervisors at Universiti Malaysia Sabah, Prof. Madya Wardatul and Dr. Asmaa who have made major contributions as well as guidance described in this paper.

\section{REFERENCES}

Ahlsén, E., \& Lundh, N. (2007). Teaching Writing in Theory and Practice: A Study of Ways of Working with Writing in the $9^{\text {th }}$ Grade. Retrieved January 21, 2018, from https://www.diva-portal.org/smash/get/diva2:199311/ FULLTEXT01.pdf

Cohen, A. D. (1996). Second Language Learning and Use Strategies: Clarifying the Issues (Revised Version). Retrieved March 23, 2018, from http://carla.umn.edu/strategies/resources/SBIclarify.pdf

Darmi, R., \& Albion, P. R. (2013, July). English Language In Malaysian Education System: Its Existence And Implication. Retrieved January 21, 2018, from https://www. researchgate.net/publication/279867616_ENGLISH_ LANGUAGE_IN_MALAYSIAN_EDUCATION_ SYSTEM_ITS_EXISTENCE_AND_IMPLICATION

Ghabool, N. (2012). Investigating Malaysian ESL Students' Writing Problems on Conventions, Punctuation, and Language Use at Secondary School Level. Retrieved January 21, 2018, from http://www.macrothink.org/ journal/index.php/jse/article/viewFile/1892/1733

Lawrence,S. etal.(2001).PersistenceofWebReferencesinScientific Research. Computer.34,26-31. doi:10.1109/2.901164, http://dx.doi.org/10.1109/2.901164.
Lee-Ann M. Kastman Breuch (2002), Post-Process "Pedagogy”: A Philosophical Exercise, JAC, Vol. 22, No. 1 (Winter 2002), pp. 119-150.

Leki, I., Cumming, A., \& Silva, T. (2008). A Synthesis of Research on Second Language Writing in English. Retrieved January 21, 2018, from http://perpus.stkipkusumanegara.ac.id/file_digital/Buku Digital 3.pdf

Nasir, L., Naqvi, S. M., \& Shelina Bhamani, S. (2013). Enhancing Students' Creative Writing Skills: An Action Research Project. Retrieved March 23, 2018, from http://dppd.ubbcluj.ro/adn/article_6_2_3.pdf

Pinto, D. (1999). SLA Research and Language Teaching by Rod Elis. Retrieved January 22, 2018, from https://escholarship.org/uc/item/7m98r12h

Sandra L. (2002). Teaching English as an International Language. Oxford University Press.

Smith, J. (1999), One of Volvo's core values. Retrieved January 25, 2018, from http://www.ijastnet.com/journal/ index/13

Strunk, W., Jr., \& White, E. B. (1979). The elements of style. ( $3^{\text {rd }}$ ed.). New York: Macmillan, (Chapter 4).

Thomas, H., Margot, H. and James, H. (1993). Second Language Reading and Vocabulary Learning. Ablex Publishing Corporation.

Time4Writing. (2017) How It Work. Retrieved January 25, 2018, from https://www.time4writing.com/how-it-works

Van der Geer, J., Hanraads, J. A. J., \& Lupton R. A. (2000). The art of writing a scientific article. Journal of Scientific Communications, 163, 51-59.

Virginia, W. B. (1994). Reading and Writing Acquisition: A Developmental Neuropsyhological Perspective, Brown \& Benchmark's Developmental Psychology Series. 